\title{
Analysis of layout and justification of design parameters of a demonstration aircraft based on solar cells
}

\author{
Volodymyr Isaienko ${ }^{1}$, Volodymyr Kharchenko ${ }^{1, *}$, Mykhailo Matiychyk ${ }^{1}$, and Inessa \\ Lukmanova $^{2}$ \\ ${ }^{1}$ National Aviation University, Kyiv, Ukraine \\ ${ }^{2}$ Moscow State University of Civil Engineering, 26 Yaroslavskoye Shosse, Moscow, 109377, Russia
}

\begin{abstract}
The development of aviation vehicles on SC (solar cells) requires, in particular, evaluations of the technical decisions made regarding the layout of future developments and obtaining their design parameters. Accordingly, it is important to take into account previous developments in the various aviation engineering fields relevant to new aviation vehicles on the SC. Thanks to a detailed analysis of the flight and performance characteristics of widely known aircraft models on the SC from the $70 \mathrm{~s}$ of the 20th century to the present, a picture of the distribution of aerodynamic schemes and important design parameters with conclusions regarding their choice is obtained. For aircraft on SC, the corresponding boundaries of their work in height and speed are determined in comparison with long-range aircraft. Also, acceptable values of unit load per unit area and specific power have been obtained that allow aircraft to be lifted on the $\mathrm{SC}$ at altitudes of at least $20 \mathrm{ths} . \mathrm{m}$. These altitudes are promising for longhaul aircraft to be operated on to SC for the purpose of performing the functions of an "aerodynamic satellite" or the so-called "pseudosatellite". The design parameters of the "pseudosatellite" demonstrator on the SC with a wingspan of $11 \mathrm{~m}$ and a starting mass of $16 \mathrm{~kg}$ were obtained.
\end{abstract}

\section{Introduction}

Formulation of the problem. Currently, solar-powered aircraft are experiencing a significant increase in the number of developments and their distribution in different parts of the world. However, researchers and designers offer their own technical solutions that do not always meet the energy capabilities of the solar cells (SC) themselves, the profound changes in atmospheric characteristics at different altitudes, the assignment of aircraft on $\mathrm{SC}$-s and other requirements.

The purpose of this article is to assess the dynamics of changes in the specific load per unit area, unit load per power unit and other important parameters for their reasonable use in the development of demonstration technologies for aircraft using SC as the main energy source.

\footnotetext{
* Corresponding author: kharch@nau.edu.ua
} 


\section{The solution to the problem}

\subsection{Development of aircraft for SC until 1990}

The problem of using sources of electric energy to drive the power plant (PP) of aircraft has been addressed since the advent of their first viable structures. An example is the airship S. Renard and A. Krebs (late 19th century) with batteries on board [1].

Also known are the facts of using electric power plants on helicopter at the beginning of the 20th century. Thus, the Austro-Hungarian PKZ group consisting of Petrucci, Karmana and Zhurovtsa demonstrated during 1917-1920 several practical designs of coaxial tethered helicopters, powered by an electric generator [2].

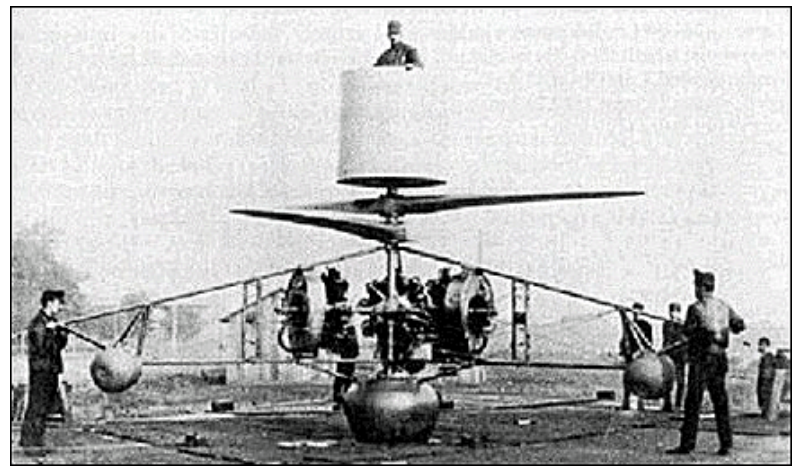

Fig. 1. Helicopter PKZ-2 on electric propulsion (1917).

The helicopters showed some success in terms of overall mass balance (payload) and electrical PP performance. However, in terms of controllability and placement on board of an acceptable electrical power source, the language was not discussed, so the project was gradually closed. This project can be considered as the first where the ability of the electric motor to be the main actuator of the aircraft of the heavier than air was proved.

The next step in the development of electric aircraft can be considered the development and successful flights of the Militky MB-E1 motor-glider with a KM77 Bosch 10kW electric motor. It was practically the first aircraft that had a purely electric drive. The source of power was Ni-Cd batteries, which in 1973 provided its flight duration of 12 min. at an altitude of up to $380 \mathrm{~m} \mathrm{[3].}$

In the direction of the direct application of solar cells, the first to be mentioned is the Mauro Solar Riser aircraft (fig.2), which was partially equipped SC with a 350Watt to recharge the onboard $\mathrm{Ni}-\mathrm{Cd}$ battery. 


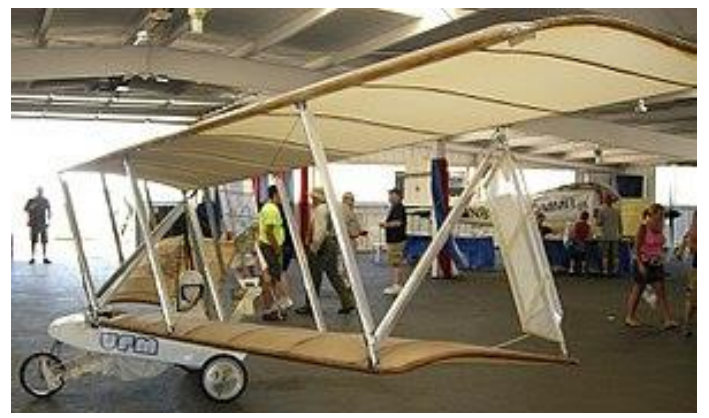

Fig. 2. The Mauro Solar Riser piloted aircraft is powered by a SC - battery.

This plane operated flights in 1979, but it was not possible to complete them completely on the SC [4]. The reason for this was the low levels of traction from PP to the SC compared to the MTOW of the aircraft, which was $125 \mathrm{~kg}$.

Meanwhile, earlier, R. Bousher (USA) on a large model aircraft AstroFlight Sunrise, and essentially an unmanned aircraft, in 1974 made a successful flight using only SC [5,6].

This development proved (fig. 3) that the combination of extremely low specific load $\left(\mathrm{p}_{0} \approx 1.4 \mathrm{~kg} / \mathrm{m}^{2}\right)$ allowed the aircraft to obtain from SC, at an efficiency of about $10 \%$, acceptable lift characteristics $\left(\mathrm{V}_{\mathrm{y}} \approx 0.8 \mathrm{~m} / \mathrm{s}\right)$, which provided its self-elevation to a height of about $2800 \mathrm{~m}$; MTOW aircraft $10 \mathrm{~kg}$ and the wingspan of about $10 \mathrm{~m}$.

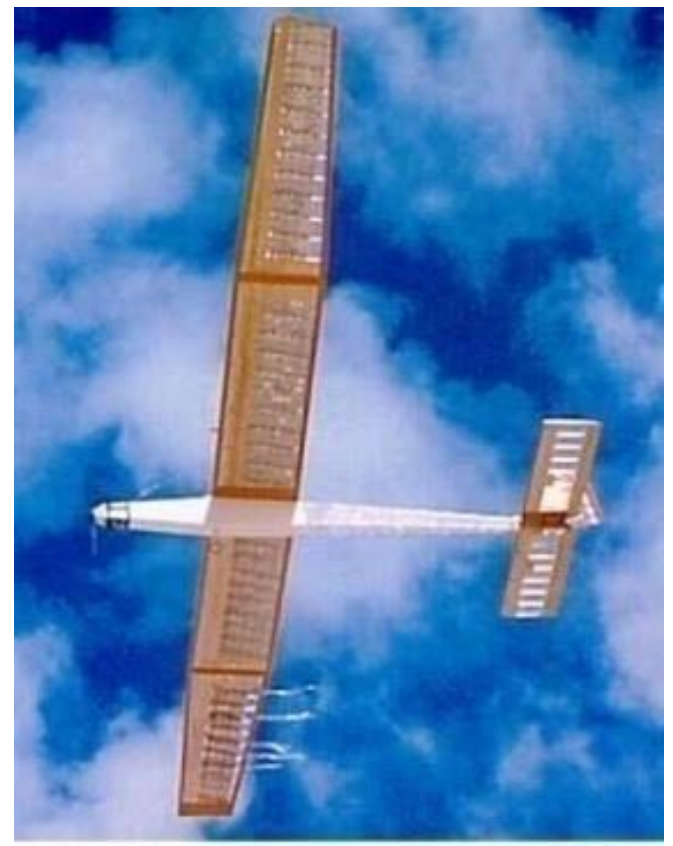

Fig. 3. Unmanned aircraft "AstroFlight Sunrise" (R. Bousher, USA, 1974).

Undoubtedly, the low speed and efficiency of the SC at the time did not allow the project to develop for practical purposes.

Much more progress has been made by P. MacCready, an American aircraft engineer whose 1977 Gossamer Albatross airplane crossed the English Channel. Since the specific power of the Gossamer Albatross aircraft was approximately $\bar{N} \approx 6 \frac{\mathrm{W}}{\mathrm{kg}}$ (due to approximate data according to which a person develops an average power of about $600 \mathrm{~W}$, and the 
Gossamer Albatross aircraft together with the pilot weighed about $100 \mathrm{~kg}$ ), it was reasonable to continue the development of his work in the direction of the on-board drive on solar cells. In 1980, with the support of DuPont, P. McCready developed a piloted Solar Challenge aircraft (fig. 4), which was powered entirely SC which are located on the wing and on the stabilizer. In 1981, he successfully completed a demonstration flight $262 \mathrm{~km}$ from France to England [7].

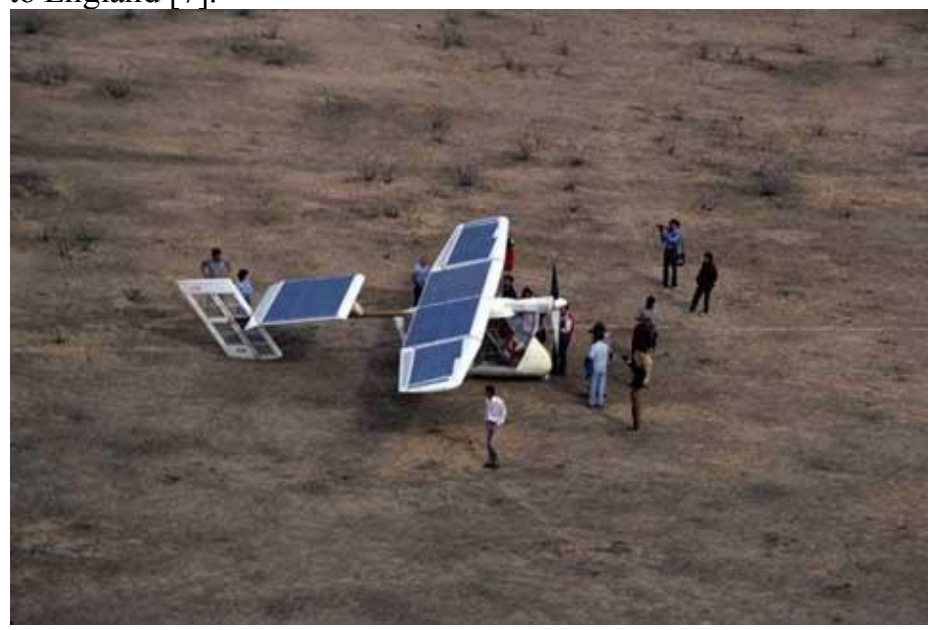

Fig. 4. Manned Aircraft "Solar Challenge" Powered by Solar Cells.

It was mounted about 17 ths. SC; it was equipped with two $2.2 \mathrm{~kW}$ electric motors and had a take-off weight of $159 \mathrm{~kg}$, which provided it with an $\bar{N} \approx 27 \frac{\mathrm{W}}{\mathrm{kg}}$ energy supply. The aircraft's lifting speed was about $\mathrm{V}_{\mathrm{y}}=0.8 \mathrm{~m} / \mathrm{s}$ and the altitude reached at $4300 \mathrm{~m}$ was in line with the calculations. Solar-powered flights showed a positive development trend, but at that time the technical level of the aircraft did not reach the required, especially regarding the use of composite construction materials, three-phase brushless motors and SC with efficiency $>20 \%$.

\subsection{Development of aircraft for SC after 1990; the Pathfinder aircraft on the SC and its modifications}

A major milestone in the development of SC aircraft is the launch in the 1980s of a government programm to develop the HALSOL altitude aircraft. The work was commissioned by AeroVironment, Inc. The new aircraft was named Pathfinder; the program intended to demonstrate the suitability of HALSOL aircraft technology as a high altitude platform for long-term surveillance [8]. 


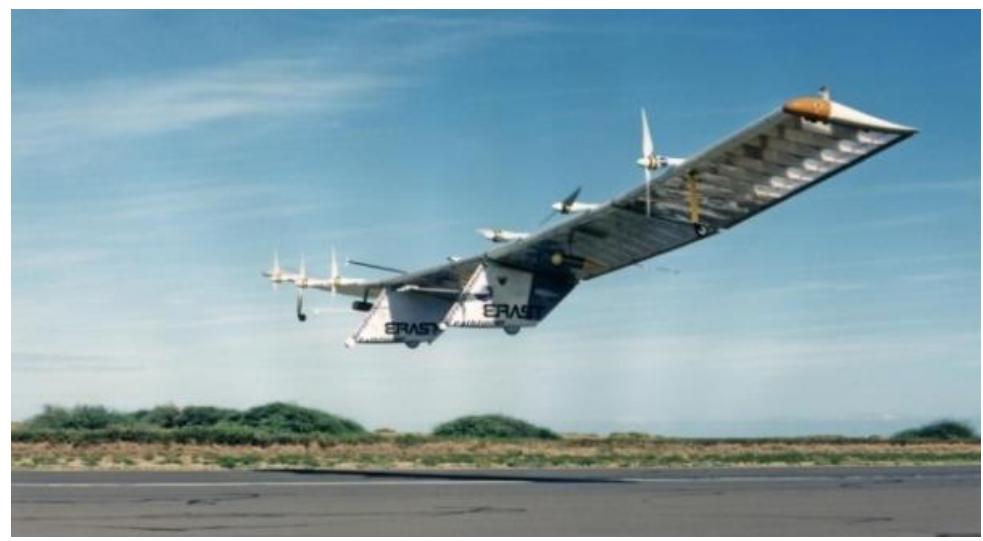

Fig. 5. Unmanned aerial vehicle Pathfinder HALSOL (High-Altitude, SOLAR) flying to SC (Hawaii Archipelago, USA).

On September 11, 1995, Pathfinder reached an altitude of 15.392 ths.m. and set a new record for aircraft on the SC. In April 1997, the Pathfinder in Dryden reached an altitude of 21.802 ths.m., which at that time was considered an absolute record for aircraft on the SC. The Pathfinder-Plus aircraft (Pathfinder modification) had a wingspan of up to $36 \mathrm{~m}$, a mass of $315 \mathrm{~kg}$ and increased its flight time to almost $20 \mathrm{~h}$. Pathfinder - Plus reached a height of 24.445 ths.m., which is 2.643 ths.m. more than Pathfinder.

The main parameters of the Pathfinder platform and its modifications Pathfinder-Plus are presented in table 1.

Table 1. The main parameters of the Pathfinder platform and Pathfinder-Plus.

\begin{tabular}{|c|c|c|}
\hline Parameter & Pathfinder & $\begin{array}{c}\text { Pathfinder- } \\
\text { Plus }\end{array}$ \\
\hline Length, $\mathrm{m}$ & 3.6 & 3.6 \\
\hline Aerodyn. chord, $\mathrm{m}$ & 2.4 & 2.4 \\
\hline Wingspan, $\mathrm{m}$ & 29.5 & 36.3 \\
\hline Aspect ratio, $\lambda$ & 12 & 15 \\
\hline Aerodynamic quality, $\mathrm{K}$ & 18 & 21 \\
\hline $\mathrm{V}_{\mathrm{C}, \mathrm{km} / \mathrm{h}}$ & $\mathrm{n} / \mathrm{d}$ & $\mathrm{n} / \mathrm{d}$ \\
\hline $\mathrm{H}_{\text {max. fl. } \mathrm{m}}$ & 21.802 & 24.445 \\
\hline $\mathrm{MTOW}_{\mathrm{N}} \mathrm{kg}$ & 252 & 315 \\
\hline Payload, $\mathrm{kg}$ & 45 & 67.5 \\
\hline $\mathrm{p}_{0}, \mathrm{~kg} / \mathrm{m}^{2}$ & 3.54 & 3.62 \\
\hline The engines, type & brushless on $1.5 \mathrm{~kW}$ \\
\hline Number of engines & 6 & 8 \\
\hline $\mathrm{N}_{\text {sum., }} \mathrm{kW}$ & 12 & 16 \\
\hline $\bar{N}, \mathrm{~W} / \mathrm{kg}$ & 35.1 & 38 \\
\hline Max. pover SC, $\mathrm{kW}$ & 7.5 & 12.5 \\
\hline Additional power source, type & \multicolumn{2}{|c|}{ Ni-Cd battery } \\
\hline
\end{tabular}

Of course, this project has shown great results, which was made possible by the emergence of flexible SC with increased to $15-17 \%$ efficiency, the use of three-phase noncollector electric motors, etc. It can be stated that the Pathfinder's energy efficiency at $\bar{N} \approx$ $35 \frac{\mathrm{W}}{\mathrm{kg}}$ is $25 \%$ higher than that of the Solar Challenge aircraft. This circumstance is key and has allowed a suitable payload of $45 \mathrm{~kg}$ to be placed on the Pathfinder, which is a significant achievement. The most basic feature of HALSOL (Pathfinder and Pathfinder-Plus) platform 
technology is the absence of any fuel consumption and the ability to create an "atmospheric satellite" that can stay over the required area for a long time, while single space satellite can control the required area for a very limited time; permanent control of the territory requires grouping of at least 24 satellites.

\subsection{NASA Centurion, Helios HP01 and Helios HP03 (USA) platforms}

Against the backdrop of successful practical results from Pathfinder and Pathfinder-Plus, AeroVironment, Inc. continued to work on increasing the size of the SC platforms. A new development was the Centurion aircraft (fig. 6) with a wingspan of $62.8 \mathrm{~m}$, inherited from the prototype (Pathfinder) scheme a flying wing of big elongation with controls - elevons located along the span and a strong arched transverse "V" and a constant aerodynamic chord which was equal to $2.4 \mathrm{~m}$. Centurion itself did not fly the on SC, but during the flights on the batteries, a valid increase in the wingspan was confirmed. MTOW has grown to $860 \mathrm{~kg}$.

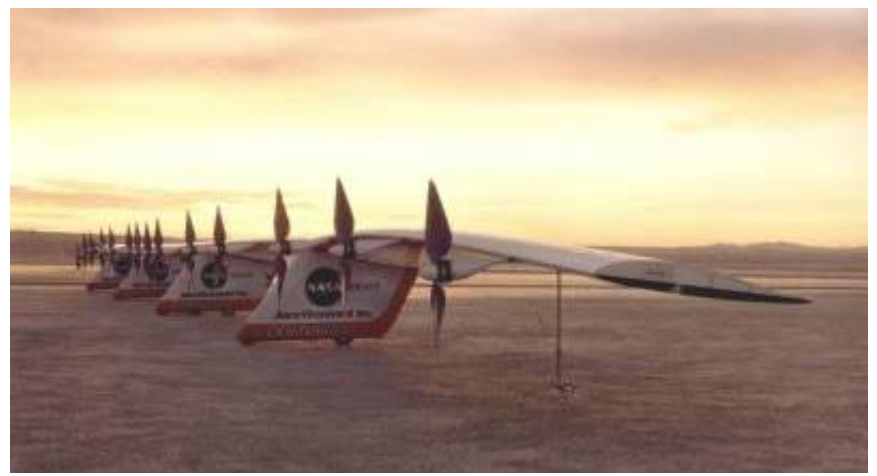

Fig. 6. Unmanned high altitude aircraft platform (aircraft -prototype Centurion, USA).

After mounting on the wing of the SC, the aircraft in 1999 was named Helios HP01 (fig. 7); it had a wingspan of $75.3 \mathrm{~m}$, its MTOW=929 kg, and 62.12 ths. SC was located on its wing [9].

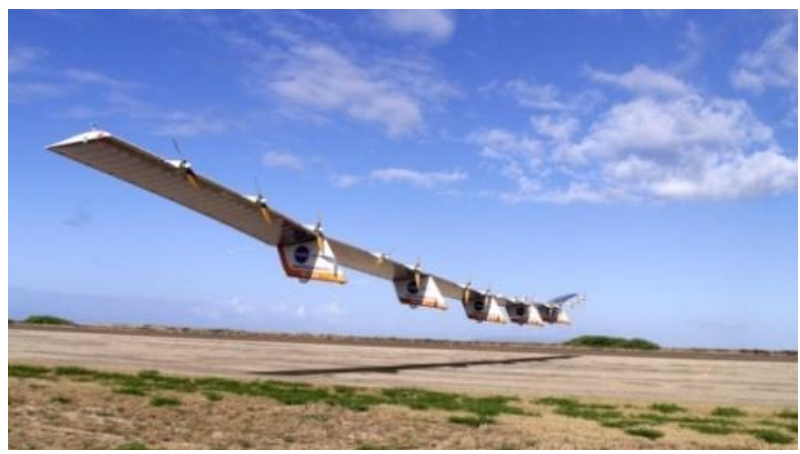

Fig. 7. Helios unmanned high altitude aircraft HP01 after takeoff (Kauai Island, Hawaii, USA). 


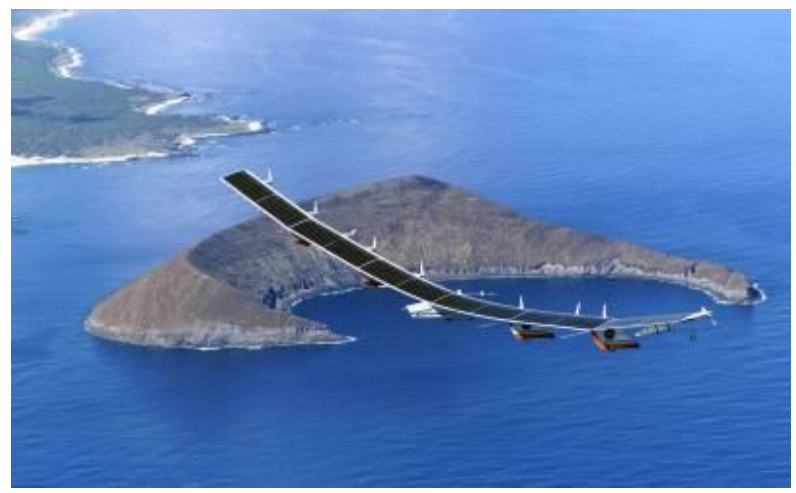

Fig. 8. Helios unmanned aerial vehicle Helios HP03 after takeoff (Kauai Island, Hawaii, USA).

During the continuation of the ERAST program (fig. 8), Helios aircraft (HP03 with additional air-hydrogen elements for flights at night) needed to demonstrate the possibility of achieving the following:

- possibility of lifting to a height of $30 \mathrm{~km}$ and staying there for 14 hours;

- show the total flight duration of up to $24 \mathrm{~h}$, of which $10 \mathrm{~h}$ was to be at an altitude of 15 $\mathrm{km}$. In terms of flight altitude, on 13 August 2001, Helios reached an altitude of 29.523 meters, which at that time was an absolute record for airplanes on the SC. At the same time, for more than 40 minutes, he steadily flew at an altitude of 29.3 ths.m. and proved that he can become an "atmospheric satellite" and able to stay at high altitude for a long time [10].

In the table 2 shows the main technical platforms of Centurion, Helios HP01 and Helios HP03 (USA).

Table 2. Main technical features of Centurion, Helios HP01 and Helios HP03 platforms.

\begin{tabular}{|c|c|c|c|}
\hline Parameter & Centurion & $\begin{array}{c}\text { Helios } \\
\text { HP01 }\end{array}$ & $\begin{array}{c}\text { Helios } \\
\text { HP03 }\end{array}$ \\
\hline Length, $\mathrm{m}$ & 3.6 & 3.6 & 5.0 \\
\hline Aerodyn.chord, m & 2.4 & 2.4 & 2.4 \\
\hline Wingspan, m & 61.8 & 75.3 & 75.3 \\
\hline Aspect ratio, $\lambda$ & 26 & 30.9 & 30.9 \\
\hline Aerodynamic quality, K & $\mathrm{n} / \mathrm{d}$ & $\mathrm{n} / \mathrm{d}$ & $\mathrm{n} / \mathrm{d}$ \\
\hline $\mathrm{V}_{\mathrm{C}}, \mathrm{km} / \mathrm{h}$ & $27-33$ & $30.6-43.5$ & $\mathrm{n} / \mathrm{d}$ \\
\hline $\mathrm{H}_{\max . \text { fl., }} \mathrm{m}$ & $\mathrm{n} / \mathrm{d}$ & 29523 & 19812 \\
\hline MTOW, kg & $\approx 862$ & 929 & 1052 \\
\hline Payload, kg & $45-270$ & 329 & $\mathrm{n} / \mathrm{d}$ \\
\hline $\mathrm{p}_{0}, \mathrm{~kg} / \mathrm{m}^{2}$ & 5.8 & 5.13 & 5.97 \\
\hline The engines, type & \multicolumn{3}{|c|}{ brushless on $1,5 \mathrm{~kW}$} \\
\hline Number of eng. & 14 & 14 & 10 \\
\hline $\mathrm{N}_{\text {sum }}, \mathrm{kW}$ & 28 & 28 & 20 \\
\hline $\bar{N}, \mathrm{~W} / \mathrm{kg}$ & 36 & 35.5 & 17.6 \\
\hline Max. pover SC, $\mathrm{kW}$ & 31 & 35 & 18.5 \\
\hline $\begin{array}{l}\text { Additional power } \\
\text { source, type }\end{array}$ & $\begin{array}{l}\text { Ni-Cd } \\
\text { battery }\end{array}$ & $\begin{array}{c}\text { Li-Po } \\
\text { battery }\end{array}$ & $\begin{array}{c}\text { Li-Po } \\
\text { battery, } \\
\text { air- } \\
\text { hydrogen } \\
\text { elements }\end{array}$ \\
\hline
\end{tabular}

On July 26, 2003, during the flight, Helios HP03 aircraft lost control, partially crashed and collapsed into the Pacific Ocean (fig. 9). 


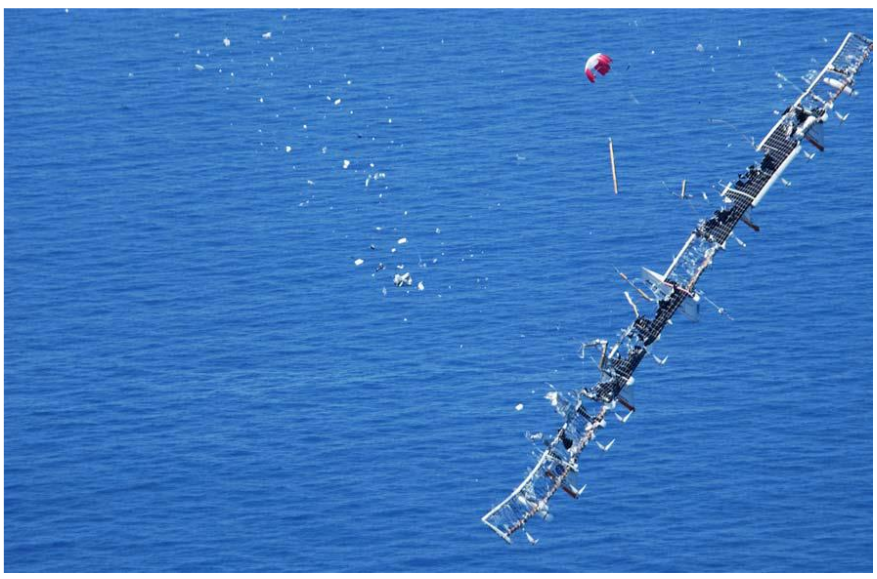

Fig. 9. Helios HP03 unmanned aerial vehicle crash (July 26, 2003).

The investigation revealed that this aviation incident was due to a coincidence of a number of circumstances, including the following [11]:

- refinement of Helios HP01 to Helios HP03 increased its MTOW by $120 \mathrm{~kg}$, but the wing spar strength did not increase;

- the Flying Wing (Helios HP03) is known to have a small margin of stability and controllability to counteract wind and turbulence shifts in the surface atmosphere;

- the strategy of raising Helios HP03 to a height did not take into account a long stay in the surface atmosphere, where turbulence reached its maximum;

- $\quad$ strength reserve of 4 units did not provide adequate durability of load-bearing structural elements in a turbulent atmosphere;

- during the climb to Helios HP03, no decision was made between the external team and the meteorological services regarding probable changes in the clouds that prevented the access of the required amount of solar energy to the aircraft.

Despite the unfortunate aviation event, the results of the tests of Centurion, Helios HP01 and Helios HP03 aircraft showed their ability to perform tasks at altitudes up to almost 30 thousand meters, with a duration of almost a day and with a mass payload of $45 \mathrm{~kg}$ to 329 $\mathrm{kg}$.

Energy availability ranged from $\bar{N} \approx 17,1 \ldots 36 \frac{\mathrm{W}}{\mathrm{kg}}$, specific load per unit area was in the range $\mathrm{p}_{0} \approx 5.13 \ldots 5,97 \mathrm{~kg} / \mathrm{m}^{2}$. A significant and significant result of work on the Pathfinder, Pathfinder-Plus, Centurion, Helios HP01 and Helios HP03 programs is the inappropriateness of the use of variable pitch screws in PP, since this complicates the design. The variable pitch screw does not give a noticeable effect for a high-altitude airplane because most of its working time it should be at altitudes of 20-30 thousand meters, and descent from the height occurs almost without the use of PP [12]. Therefore, the problem is to obtain an acceptable efficiency of the constant pitch screw on take-off.

\subsection{Solar Impulse manned aircraft, Zephyr pseudo sattelite and other development of high-altitude aircraft with SC in the period 2007-2016}

In 2003-2016, in Switzerland, under the leadership of B. Picar and A. Borsberg, a Solar Impulse aircraft (fig. 10) was developed to prove that the future of aviation was through green, electric power sources, including the symbiosis of SC and Li-Po batteries. The Solar 
Impulse aircraft was preparing for long flights at altitudes of about 8 ths.m.; the duration should gradually increase and finish a flight around the globe.

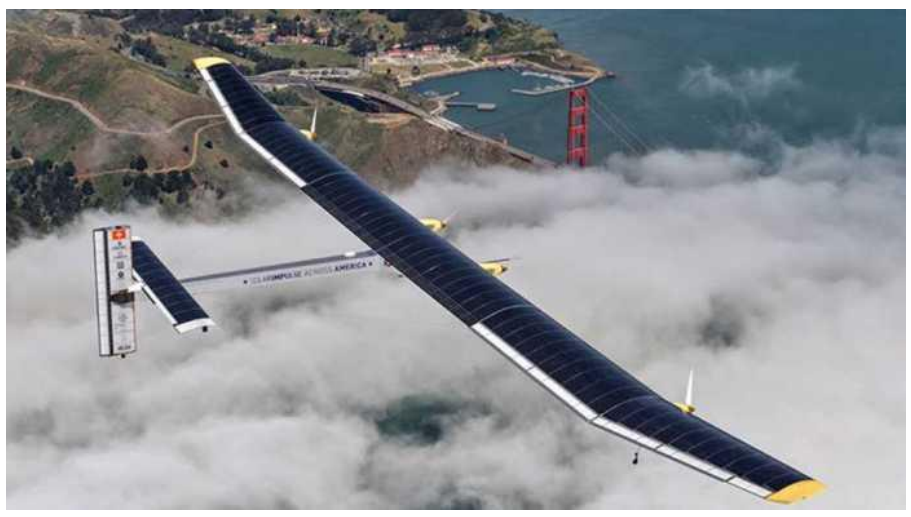

Fig. 10. Solar Impulse aircraft in flight.

Solar Impulse aircraft is built by normal aerodynamic scheme and is equipped with four electric motors with a total capacity of up to $70 \mathrm{hp}$. with MTOW $2300 \mathrm{~kg}$; of these, about $600 \mathrm{~kg}$ weighed Li-Po batteries.

Edge modification of Solar Impulse HB-SIB with MTOW=2300 kg made a round-theworld flight with intermediate landings, during which a record result of continuous flight of $7200 \mathrm{~km}$ for $117 \mathrm{~h}$ of flight time was obtained; CAS speed $=34-103 \mathrm{~km} / \mathrm{h}$.

The technical data of the aircraft HB-SIB board is given in the summary table 3 , and developed on the basis of primary sources [13-16].

Table 3. Main specifications of the aircraft HB-SIB (Solar Impulse, Switzerland).

\begin{tabular}{|c|c|}
\hline Parameter & The Value \\
\hline Power plant \\
\hline Engines, $\mathrm{kW}$ & $4 \times 17.4$ \\
\hline Turn the motor shaft, rpm. & 525 \\
\hline Diam. airscrew, m (number of blades) & $4(2)$ \\
\hline PP efficiency, \% $\mathrm{94}$ \\
\hline Distance between engines, $\mathrm{m}$ & 4.95 \\
\hline \multicolumn{2}{|c|}{ Battery and SC } \\
\hline Mass of Li-Po batteries, $\mathrm{kg}$ & 633 \\
\hline Battery power, $\mathrm{kWxh}$ & 38 (inc/d) \\
\hline Mass energy output, W h/kg & 260 \\
\hline Solar cells, ths. pcs & 17.248 \\
\hline Area SC, ${ }^{2}$ & 270 \\
\hline SC efficiency, $\%$ & 22.5 \\
\hline SC protection; thickness, $\mu \mathrm{m}$ & 17 \\
\hline SC thickness, $\mu \mathrm{m}$ & 35 \\
\hline Parameter the structure HB-SIB \\
\hline Wingspan, $\mathrm{m}$ & 72.3 \\
\hline Aerodynamic chord, $\mathrm{m}$ & 2.7 \\
\hline Wingarea, ${ }^{2}$ & 278 \\
\hline Length, $\mathrm{m}$ & 22.4 \\
\hline
\end{tabular}




\begin{tabular}{|c|c|}
\hline Height, $\mathrm{m}$ & $\mathrm{n} / \mathrm{d}$ \\
\hline Flight altitude, ths. $\mathrm{m}$ & 8 (inc/d) \\
\hline MTOW, $\mathrm{kg}$ & 2300 \\
\hline Empty aircraft mass in SC, $\mathrm{kg}$ & 1527 \\
\hline $\mathrm{p}_{0}, \mathrm{~kg} / \mathrm{m}^{2}$ & 8.3 \\
\hline $\bar{N}, \mathrm{~W} / \mathrm{kg}$ & 21.13 \\
\hline Max. speed, $\mathrm{km} / \mathrm{h}$ & 140 \\
\hline Cruising speed, $\mathrm{km} / \mathrm{h}$ & 75 \\
\hline Lift-off speed, $\mathrm{km} / \mathrm{h}$ & 35 \\
\hline Range (of an aircraft), ths. $\mathrm{km}$ & 8.2 (inc/d) \\
\hline Flight duration, $\mathrm{h}($ days) & 117 (to 6 ) \\
\hline \multicolumn{2}{|c|}{ Flight restrictions } \\
\hline Max. wind start speed, $\mathrm{m} / \mathrm{s}$ & 2.5 \\
\hline Max. headwind, $\mathrm{m} / \mathrm{s}$ & 1.5 \\
\hline Max. headwind when landing, $\mathrm{m} / \mathrm{s}$ & 3.5 \\
\hline V $_{\text {y.max. } \text { in turbulent atmosphere, } \mathrm{m} / \mathrm{s}}$ & 2 \\
\hline
\end{tabular}

The above characteristics of the Solar Impulse project prove that its energy efficiency is slightly lower than Pathfinder-Plus and decreased from $36 \mathrm{~W} / \mathrm{kg}$ in Pathfinder-Plus to 21.13 $\mathrm{W} / \mathrm{kg}$. This can be explained by the fact that Solar Impulse had a completely different purpose; its working heights of 8-9 thousand are those which are characterized by high wind loads and it should have large reserves of durability and correspondingly greater mass. This can also explain the high specific load per unit area $-8.3 \mathrm{~kg} / \mathrm{m}^{2}$, which is 2.3 times more than in Pathfinder-Plus. From this we can conclude that the Solar Impulse aircraft is not designed for high altitude flights and its relatively low energy availability does not allow to have adequate excess capacity for lifting to a height of 20 thousand $\mathrm{m}$. In spite of this, the results obtained from the design and operation of Solar Impulse are significant for the direction of the development of high altitude aircraft in the following:

- it has been proved the long stay of an electric aircraft with the corresponding payload (pilot + equipment) for $117 \mathrm{~h}$ in airspace, at given altitudes and in sufficiently active layers of the atmosphere;

- $\quad$ proved the possibility of operation of the specified aircraft within the conventional aerodrome infrastructure, communications and civil aviation control service;

- $\quad$ obtained the ratio between the number and area of the SC, the mass of the onboard batteries and MTOW of the aircraft, in which the target load is about $9 \%$;

- $\quad$ Technologically, it has been proven that high strength and light weight can be obtained with the use of composite materials, in particular on the basis of fibers and fabrics of carbon, kevlar and other technical fibers.

\subsection{Unmanned "atmospheric satellite" Zephyr}

Since 2003, the British company QinetiQ, together with the UK MoD, has been developing a family of high-altitude Zephyr (HALE) aircraft (atmospheric satellite, pseudosatellite) in SC that can provide high-quality surveillance in large areas [17].

Several prototypes were produced and tested, which were mainly different with wing span and MTOW. At the same time, the general aerodynamic scheme was preserved: a free-bearing mid-plane with a "U" -like wing, a "T" -like or normal tail and two motors arranged in cross (fig. 11). 


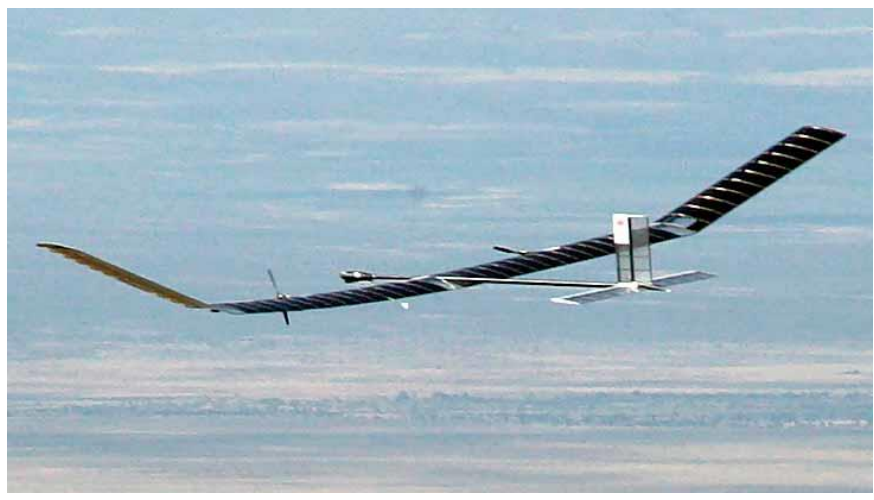

Fig. 11. One of the later prototypes of a high-altitude aircraft on the SC Zephyr -6 .

In 2010, the Zephyr aircraft set world records for an altitude of 21.561 ths.m and a flight duration of 14 days (336 hours 22 minutes). At the time of 2016, the UK MoD announced the purchase of Zephyr pseudosatellite samples for exploration and surveillance purposes [18]. In this development, the previous world experience of similar aircraft designs was taken into account, namely:

- selected the most viable aerodynamic circuit, the so-called normal, which allowed to optimize the internal structure and rationally position solar cells, power plants and onboard radio and other equipment, achieved acceptable values of stability and controllability;

- the Zephyr design uses a well-known cross-channel control using cross-links from the channel (rudder) to perform uncoordinated turn / reversal;

- from uncontrolled roll increase the aircraft is restrained by a significant increase in lateral stability (use of "U" - like wing);

- the use of this technical solution made it possible to exclude from the design special transverse controls - ailerons, as an element that may cause additional torque and further probable development of the flutter or divergence up to the destruction of the wing.

Some technical data of the Zephyr pseudosatellites are given in table 4.

Table 4. Some technical data of the «Zephyr $-7 »$ pseudosatellites.

\begin{tabular}{|c|c|}
\hline Parameter & The Value \\
\hline Engine power, $\mathrm{kW}$ & $2 \times 0.45=0.9$ \\
\hline Wingspan, $\mathrm{m}$ & 22.5 \\
\hline Wingarea, $\mathrm{m}^{2}$ & 20 \\
\hline Length, $\mathrm{m}$ & 10.3 \\
\hline Height, $\mathrm{m}$ & 1.6 \\
\hline Flight altitude, $\mathrm{m}$ & 21000 \\
\hline MTOW, $\mathrm{kg}$ & 53 \\
\hline Empty aircraft mass in SC, $\mathrm{kg}$ & 51.5 \\
\hline Mass payload, $\mathrm{kg}$ & 2.5 \\
\hline $\mathrm{p}_{0}, \mathrm{~kg} / \mathrm{m}^{2}$ & 2.65 \\
\hline $\bar{N}, \mathrm{~W} / \mathrm{kg}$ & 17 \\
\hline Cruising speed, $\mathrm{m} / \mathrm{s}$ & 15.6 \\
\hline
\end{tabular}

The Zephyr project is currently considered the most successful and technologically advanced and is part of Airbus's High-Altitude Pseudo-Satellite (HAPS) program. QinetiQ's Zephyr project has played an extremely important role in the development of airplanes for SC considering the following: 
- the aerodynamic scheme suitable for the construction has been finally determined, the so-called normal one, and it has been proved that the U-shaped wing can provide an acceptable level of stability in the absence of transverse controls;

- the use of the increased rudder provides acceptable control of the course and the transverse channel;

- these circumstances have greatly simplified the pseudo-satellite control system, lowered its cost and improved reliability;

- during the implementation of this project, the values of the specific wing load and energy parameters were determined, which are respectively $2.65 \mathrm{~kg} / \mathrm{m}^{2}$ and $17 \mathrm{~W} / \mathrm{kg}$.

Analysis of the values obtained and the design of Zephyr shows that the specific load of $2.65 \mathrm{~kg} / \mathrm{m}^{2}$ is the lowest today; the closest specific load value of $3.54 \mathrm{~kg} / \mathrm{m}^{2}$ belongs to the prototype Pathfinder (1993), which indicates the need to maintain a high level of "culture of weight" and the widespread use of modern structural materials, including composites.

\subsection{Other development of high-altitude aircraft with SC in the period 2007- 2016}

Among the landmark developments presented by the developers and manufacturers of aviation equipment in the period 2007-2016, the Aquila (USA) project developed by Facebook, Inc. (fig. 12) is the first. It was intended to be used to create Internet networks in remote areas of the Earth.

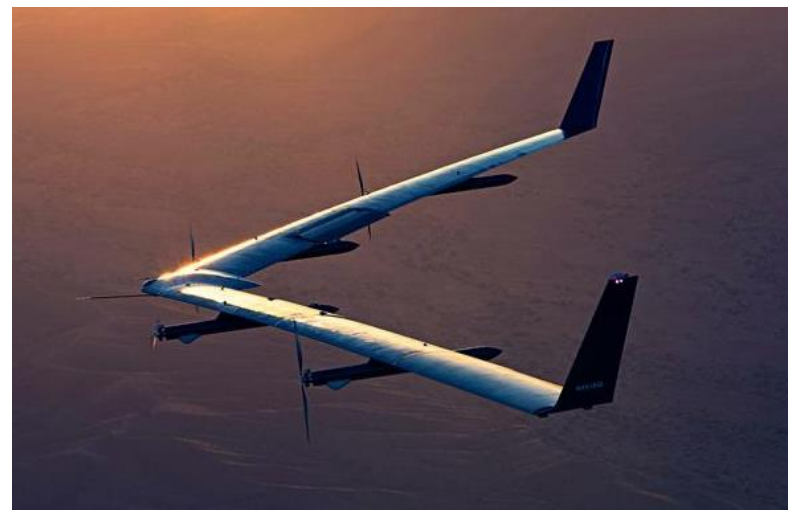

Fig. 12. Aquila unmanned aerial vehicle (Facebook, Inc. USA. 2014-2018).

According to the aerodynamic scheme, the aircraft was a flying wing that had an effective elongation of about 17 units, a wingspan of $42 \mathrm{~m}$ and a take-off weight of $400 \mathrm{~kg}$. The load per unit area is $3.47 \mathrm{~kg} / \mathrm{m}^{2}$ and the energy supply was within $13 \mathrm{~W} / \mathrm{kg}$. The performed test flights showed the overall viability of the circuit, but for reasons that the leadership of Facebook, Inc. not announced, in 2018 the project was closed [19].

Also known was the Project "Titan Aerospace" (USA) called Solara 50/60 (fig. 13). It was planned as a pseudo-satellite; the wingspan was $50 / 60 \mathrm{~m}$ and the declared payload was $30 / 50 \mathrm{~kg}$. The air time was estimated at least 90 days and the flight altitude was 20 ths. $\mathrm{m}$ [19]. According to preliminary estimates, multispectral imaging of the Earth's surface was only $5 \$ / \mathrm{km}^{2}$, which is 7 times lower than the rates for satellite data of comparable quality. It is also possible to note perfect solutions in the use of one slow-moving air screw, which allowed to unload the wings from the motors. It should also be noted the maximum number of SC that could be placed on the surfaces of the pseudo-satellite. 


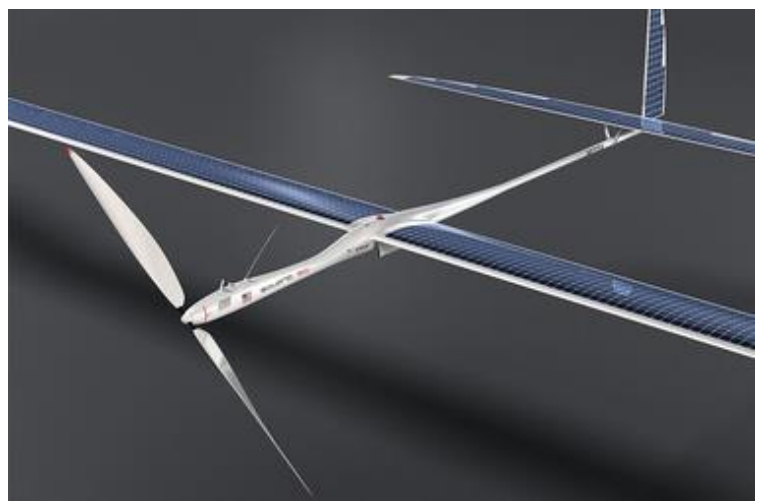

Fig. 13. Appearance of unmanned aerial vehicle - Solara pseudosatellite by Titan Aerospace, USA (2014).

The tandem aerodynamic scheme was used in the ApusDuo unmanned aerial vehicle (fig. 14). It was developed and tested by a startup UAVOS (USA). The application of the tandem scheme is rare and is associated with the solution of typical problems: ensuring the rigidity and strength of a given spatial structure, its behavior in flight in terms of ensuring the appropriate level of stability and controllability, and others. Despite this, a plane with a wingspan of $10 \mathrm{~m}$ was successfully tested [20].

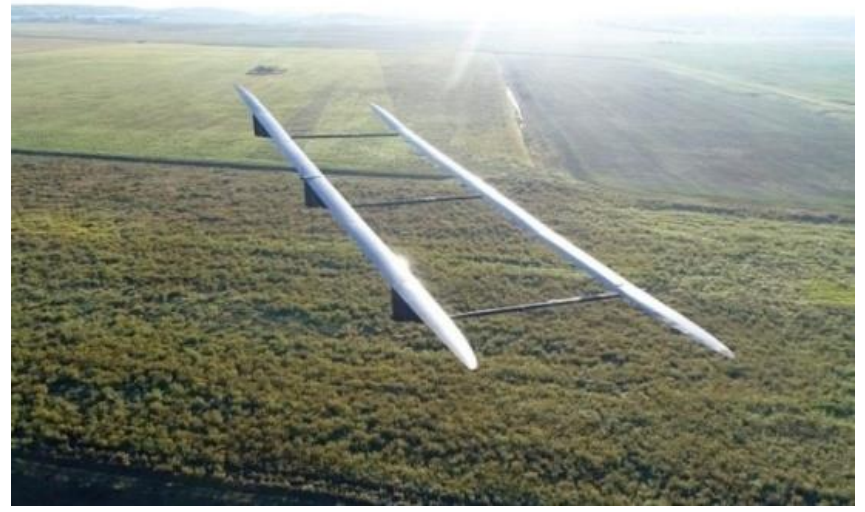

Fig. 14. Unmanned Aerial Vehicle - ApusDuo Pseudo-Satellite from UAVOS Startup, USA (2018).

It is safe to say that the trends in the development and testing of unmanned aerial vehicles as pseudosatellites have been positive and increasing in recent years. Many countries are, in fact, involved in some sort of technological race for the development of heights of 20 ths.m. or more in order to control areas with a high degree of efficiency to obtain high-quality species information. Additionally, on this issue, one can add BAE Systems work on PHASA-35, the South Korean EAV-3 project from the KARI Institute, and dozens of others [21].

\section{Justification of the alleged flight conditions of the aircraft on solar cells}

The choice of aerodynamic design, overall layout and powerplant of the aircraft on the SC will also be affected by the limitations that arise from the assessment of its future operation 
in the airspace. This can be clearly demonstrated in the altitude-speed co-ordinates compared to other known aircraft types.

In fig. 15 altitude-velocity coordinates show the curves of the speed limit for the longhaul aircraft (LHA) $\left(\mathrm{V}_{\text {min.LHA }}\right.$ and $\left.\mathrm{V}_{\max \text {. LHA }}\right)$ and the restrictions for the aircraft on solar cells (ASC) ( $\mathrm{V}_{\text {min.ASC. }}$ and $\mathrm{V}_{\text {max.ASC. }}$ ).

Usually, the modes for LHA are limited to the calculation (the branches of the curve $\mathrm{V}_{\text {min.LHA }}$ and $\mathrm{V}_{\text {max. LHA }}$ ), the acceptable values of the velocity head, by taking into account the indicator velocity (curve $\mathrm{V}_{\text {i.min.LHA }}$ ) and the number $\mathrm{M}_{\max }$. [22]. Accordingly, at altitudes close to $0 \mathrm{~m}$, the speed of the LHA aircraft varies between $80-180 \mathrm{~m} / \mathrm{s}$; at altitudes of about 8 ths. $\mathrm{m}$ the speed range expands from $100 \mathrm{~m} / \mathrm{s}$ to $160 \mathrm{~m} / \mathrm{s}$.

The operating echelons of 8-12 ths.m. are marked with the letter A. At altitudes of 12 ths. $\mathrm{m}$. the speed range is reduced to about $110 \mathrm{~m} / \mathrm{s}$, which is dictated by the most favorable speed by the number $\mathrm{M}_{\max }$. (marked with a dashed line). Increasing the minimum speed at altitudes of 8 to 12 ths.m. is associated with an increase in the stalling speed due to the drop in air density. Shaded Zone C corresponds to the operational modes for LHA and displays the corresponding heights and speeds.

For the aircraft on the $\mathrm{SC}$, the velocity curves for altitudes are indicated as $\mathrm{V}_{\text {min.ASC. }}$ and

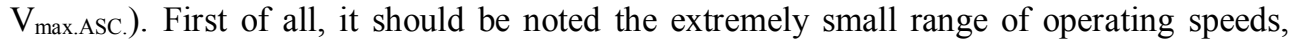
which is: $\mathrm{V}_{\text {max.ASC. }}-\mathrm{V}_{\min . A S C}=35.5-5.5=30 \mathrm{~m} / \mathrm{s}$. It is taken from its comparison with the speed range of the LHA, which averages (for all operating altitudes) about 180-190 m/s, which is more than 6 times the speed range of the aircraft on the solar cells.

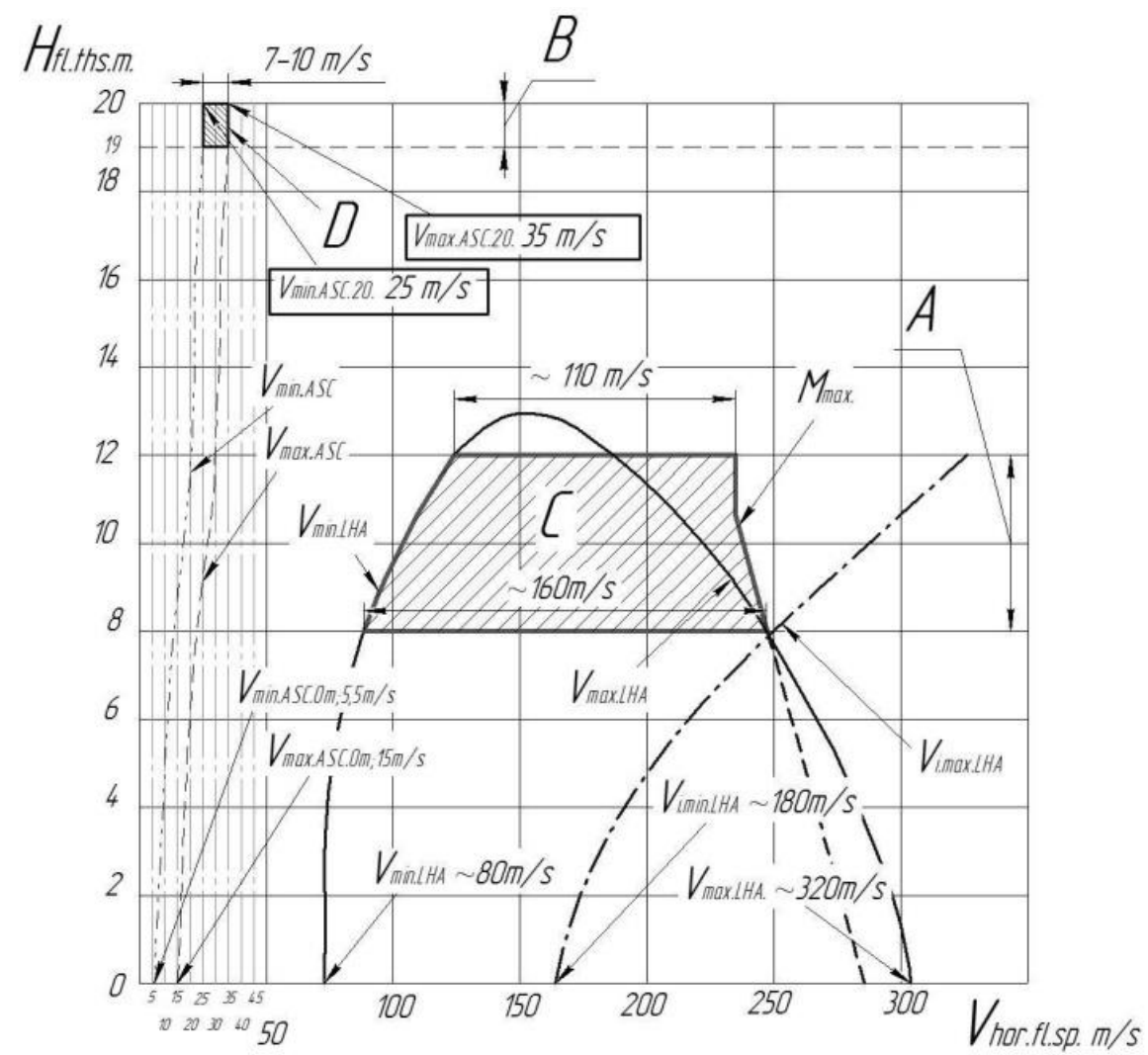

Fig. 15. Velocity curves for the aircraft LHA and for the ASC. 
From this we can conclude that the aircraft on the SC will be sensitive to fluctuations in speed and atmospheric conditions at different altitudes. Also, excessive sensitivity is manifested by the fact that the $\mathrm{p}_{0}$ of the pseudosatellite is in the range of $\mathrm{p}_{0}=2.5-3 \mathrm{~kg} / \mathrm{m}^{2}$, whereas this indicator for LHA is in the range of $p_{0}=280-300 \mathrm{~kg} / \mathrm{m}^{2}$. At the same time, the extremely low $\mathrm{p}_{0}$ value of the pseudo-satellite is dictated by the extremely low SC indicators, which ensure the thrust-weight ratio of the ASC at the level of $0.09-0.15 \mathrm{kGf} / \mathrm{kg}$, while for LHA the typical indicator is $0,5 \mathrm{kGf} / \mathrm{kg}$ for the takeoff mode. The range of operational heights of 19-20 ths.m of the ASC, in role a pseudo satellite (marked with the letter B) is dictated by its main task - monitoring the territory with optical means. According to the increase in height, the area of capture of the territory by the lens of the optical means increases; operation of the pseudosatellite at altitudes of 18 ths.m. and below becomes unprofitable. Operating speeds are limited to $V_{\text {max. }}=35 \mathrm{~m} / \mathrm{s}$ and $V_{\text {min. }}=25 \mathrm{~m} / \mathrm{s}$. The speed $V_{\text {min }}$, which is associated with a significant drop in air density, to $0.089 \mathrm{~kg} / \mathrm{m}^{3}$ (at an altitude of $0 \mathrm{~m}$ this indicator in summer is: $\rho_{\text {air. }}=1,225 \mathrm{~kg} / \mathrm{m}^{3}$ ) [23].

The maximum speed is limited by the characteristics of the PP and the main power source - SC. Accordingly, the figure indicated by the letter D shows the values of speeds and heights, for which the pseudo-satellite is suitable for its intended purpose. These flight modes apply during operation. Flight modes below 18 ths.m. are auxiliary and are used only for raising and lowering the pseudosatellite. Comparing the areas of figures D and C, as well as the velocity curves, we can draw the following conclusions:

- $\quad$ operating modes for speeds and heights for LHA and pseudo-satellite vary greatly due to their different purposes and a significant difference in power supply;

- acceptable modes of operation of the pseudo-satellite to perform its basic functions as a carrier of optical means for monitoring territories are located in the coordinates of height and speed within $\mathrm{H}_{\mathrm{fl}}=18-20$ ths.m. and up to $\mathrm{V}_{\mathrm{fl}}=25-35 \mathrm{~m} / \mathrm{s}$;

- heights from 0 to $18 \mathrm{~km}$ are used only for lifting and lowering pseudosatellite; respectively the branch of the curve $\mathrm{V}_{\text {max.ASC }}$ can be implemented for glider descent;

- for the successful implementation of high-speed descent, it is necessary to minimize the harmful resistance of the pseudosatellite, especially in terms of hiding the propeller blades along the stream;

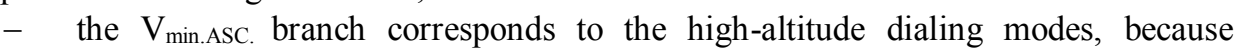
$\mathrm{V}_{\mathrm{y} \text {.max.ASC. }}$ it is connected with $\mathrm{V}_{\text {min.ASC. }}$ by the cosine of the angle of elevation of the pseudosatellite, which ensures maximum lifting speed.

\section{Results of justification of the layout scheme and design parameters of the aircraft on the SC in the first approximation}

The scope of unmanned aerial vehicles for airplanes in the future is defined as revenue generation for the airline operator operating A4 aircraft (aviation works) in the field of aerial photography.

In the analysis of previous developments of aircraft with SC with a mass of up to $2300 \mathrm{~kg}$, the characteristics of 23 aircraft of various classes were processed, in particular, the following samples were processed (table 5).

Table 5. Projects aircraft on the SC for the period 1974-2019 years.

\begin{tabular}{|c|c|c|c|}
\hline № & Project name & $\begin{array}{c}\text { Year of } \\
\text { production }\end{array}$ & Country \\
\hline 1 & AstroFlight Sunrise & 1974 & USA \\
\hline 2 & Mauro Solar Riser (ПC) & 1979 & USA \\
\hline 3 & Gossamer Penguin & 1979 & USA \\
\hline 4 & Solar Challenge & 1980 & USA \\
\hline 5 & Pathfinder & 1993 & USA \\
\hline
\end{tabular}




\begin{tabular}{|c|c|c|c|}
\hline 6 & Pathfinder-Plus & 1998 & USA \\
\hline 7 & Centurion & 1999 & USA \\
\hline 8 & Helios HP01 & 2001 & USA \\
\hline 9 & Helios HP03 & 2002 & USA \\
\hline 10 & Solar Impulse & 2003 & Switzerland \\
\hline 11 & Zephyr-6 & 2010 & G.B. \\
\hline 12 & ELHASPA & 2011 & Germany \\
\hline 13 & Aquila & 2014 & USA \\
\hline 14 & Sunseeker Duo & 2014 & Italy \\
\hline 15 & Solara 50/60 & 2015 & USA \\
\hline 16 & AtlantikSolar & 2015 & Switzerland \\
\hline 17 & EAV-3 & 2015 & South Korea \\
\hline 18 & Zephyr-T & 2016 & G.B. \\
\hline 19 & EIAST & 2016 & UAE \\
\hline 20 & Caihong & 2017 & China \\
\hline 21 & Apus Duo & 2018 & USA \\
\hline 22 & Owl & 2018 & Russia \\
\hline 23 & PHASA-35 & 2019 & G.B. \\
\hline
\end{tabular}

Distribution by countries - developers and the number of their aircraft projects on SC:

- USA - 12 (52.2\%);

- Great Britain - $3(13 \%)$;

- Switzerland - 2 (8.6\%);

- China - $1(4.3 \%)$;

- Germany - $1(4.3 \%)$;

- Italy - 1(4.3\%);

- South Korea - 1(4.3\%);

- UAE - 1(4.3\%);

- Russia - 1 (4.3\%).

Airplanes distribution by layout scheme*:

1 eng.+ PLS, + NAS - $5(21.7 \%)$;

2 eng. + PLS, + NAS - $6(26 \%)$;

4 eng.+ PLS, + NAS -1 (4.3\%);

7 eng.+ PLS, + NAS -1 (4.3\%);

2 eng.+ PLS, + 2 NAS - 1 (4.3\%);

2 eng.+ PLS, +3 NAS -1 (4.3\%);

4 eng.+ PLS, + SFW -1 (4.3\%);

6 eng. + PLS, + SFW - $1(4.3 \%)$;

8 eng. + PLS, + SFW - 1 (4.3\%);

10 eng.+ PLS, + SFW - 1 (4.3\%);

14 eng.+ PLS, + SFW - $1(4.3 \%)$;

1 eng.+ PSS, + SFW -1 (4.3\%);

1 eng.+ PSS, + TS - 1 (4.3\%);

1 eng. + PSS, $+\mathrm{CC}-1(4.3 \%)$.

* Note (abbreviation):

$N A S$ - normal aerodynamic scheme;

2NAS- 2 beams, norm. scheme;

$3 N A S$ - 3 beams, norms. scheme;

SFW - scheme Flying Wing;

TS - tandem scheme;

$C C$ - canard configuration;

2eng. - two engine; 
PLS - pulling screw;

PSS - pushing screw.

On the basis of data processing of parameters of specific power $\bar{N}, \mathrm{~W} / \mathrm{kg}$ and load per unit area $\mathrm{p}_{0}, \mathrm{~kg} / \mathrm{m}^{2}$, dynamics of their change during 1970-2016 years was obtained.

In fig. 16, the extreme values of the specific power $\bar{N}, \mathrm{~W} / \mathrm{kg}$, form a dashed field. All points on the field correspond to the values of $\bar{N}, \mathrm{~W} / \mathrm{kg}$, which at one time had specific aircraft (table 5).

In connection with the improvement of technological perfection of both the SC itself and the layout of the aircraft, this parameter gradually decreased its range. Yes, in the 80s of the 20th century and the beginning of the 21 st century. the range ranged from 18 to 38 $\mathrm{W} / \mathrm{kg}$, (size A and B in fig. 16), indicating uncertainty in approaches to establishing the mass, geometric, and energy characteristics of airplanes on SC. Subsequently, with the appearance of SC with an efficiency of about $20 \%$, the range of values of the parameter $\bar{N}, \mathrm{~W} / \mathrm{kg}$ narrowed and at the moment of 2016 it is in the range of $26-28 \mathrm{~W} / \mathrm{kg}$ (size C in fig. 16), which is sufficient for today to provide lifting of the aircraft with the help of SC to the height of 20 ths. $\mathrm{m}$.

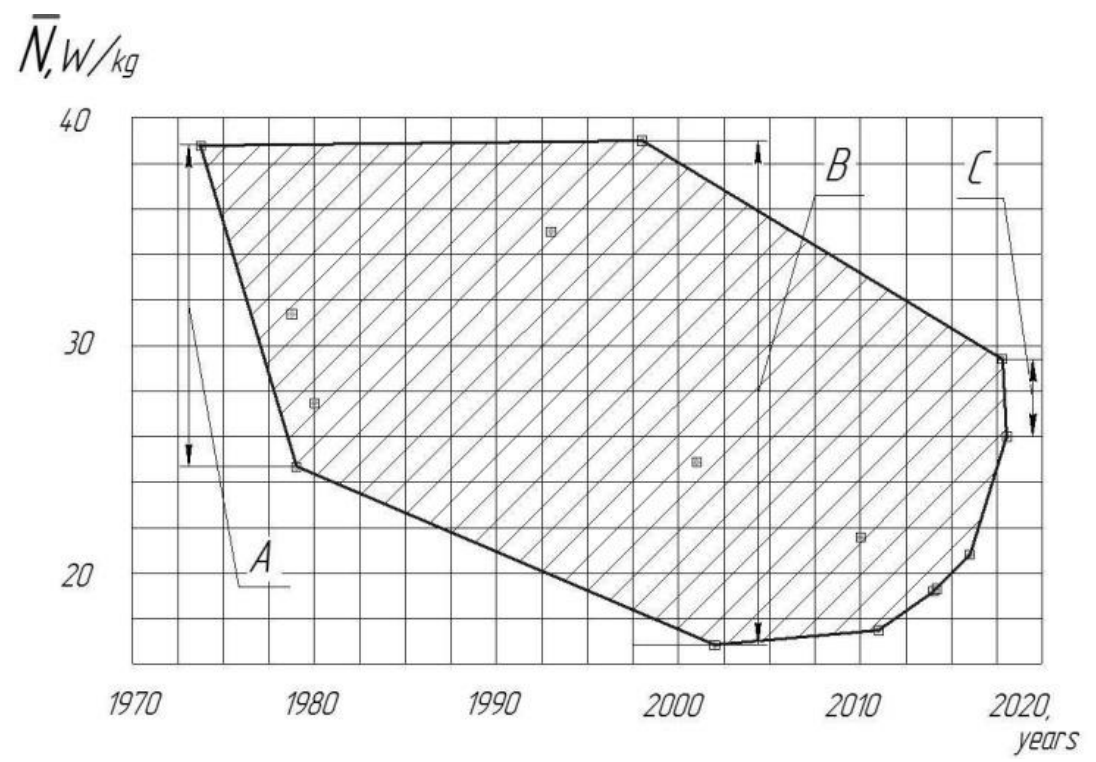

Fig. 16. Distribution of parameter $\bar{N}, \mathrm{~W} / \mathrm{kg}$ for SC planes during 1970-2016.

According to a similar scheme, the dynamics of changes in the specific load per unit area (fig.17) was evaluated as an indicator that directly affects the inductive component of aerodynamic resistance and, accordingly, the aerodynamic quality of $\mathrm{K}$. 


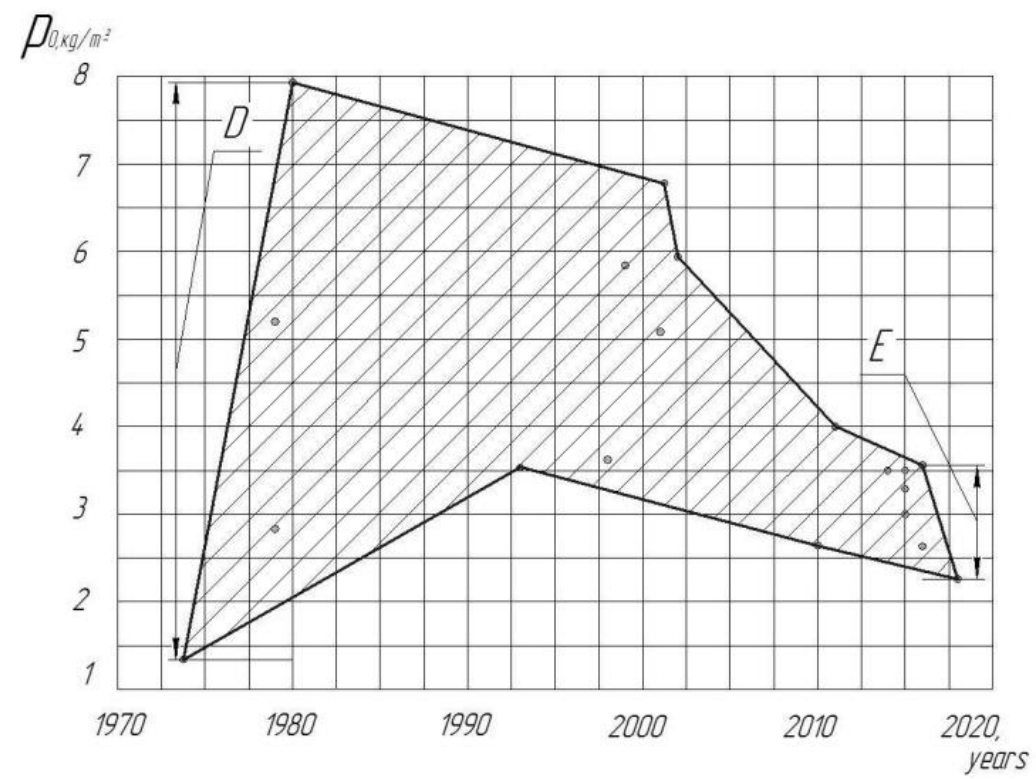

Fig. 17. Distribution of parameter $\mathrm{p} 0, \mathrm{~kg} / \mathrm{m} 2$ for on SC planes during 1970-2016.

In the $70-80 \mathrm{~s}$ of the 20th century, the range ranged from 0.6 to $8 \mathrm{~kg} / \mathrm{m}^{2}$ (size D in Fig. 17), which indicates the use of different approaches to determine the mass and geometric characteristics of airplanes on SC. Subsequently, with the advent of SC with an efficiency of about $20 \%$ and with the expansion of the field of application of composite materials, the range of the parameter $p_{0}$ narrowed, and at the time of 2016 it was approximately in the range of $2.3-3.6 \mathrm{~kg} / \mathrm{m}^{2}$ (size $\mathrm{E}$ in fig. 17), which today correlates well with the parameter $\bar{N}, \mathrm{~W} / \mathrm{kg}$.

The average, minimum and maximum values of the main parameters of the investigated pseudo-satellites and aircraft on SC are given in table 6.

Table 6. The values of the main parameters of the investigated aircraft and pseudosatellites.

\begin{tabular}{|c|c|c|c|c|}
\hline № & Parameter & $\begin{array}{c}\text { Min. } \\
\text { value }\end{array}$ & Max. value & $\begin{array}{c}\text { Average } \\
\text { value }\end{array}$ \\
\hline 1 & $\bar{N}, \mathrm{~W} / \mathrm{kg}$ & 17 & 38 & $28.5^{*}$ \\
\hline 2 & $\begin{array}{c}\bar{m}_{\text {spec.load }} \\
\mathrm{Kg} / \mathrm{W}\end{array}$ & 0.058 & 0.026 & $0.035^{*}$ \\
\hline 3 & $\mathrm{p}, \mathrm{kg} / \mathrm{m}^{2}$ & 0.6 & 8.3 & $4.35^{* *}$ \\
\hline 4 & $\mathrm{MTOW}, \mathrm{kg}$ & 10 & 2300 & $100^{* * *}$ \\
\hline
\end{tabular}

The note. The number of aircraft processed, due to incomplete data, including:

* - data of 8 aircraft were processed;

** -6 aircraft processed;

*** - 3 aircraft data processed.

Air screws for these aircraft are used with fixed pitch and number of blades 2 .

\section{The predicted composition of the onboard electrical installation of the aircraft in SC}


The on-board electrical installation of the aircraft on the SC shall consist of photovoltaic cells (for example, S-60 Sunpower, $125 \mathrm{~mm}$ x $125 \mathrm{~mm}$, GEN II models) located on its surface, in particular:

- SC on the tail beam surface;

- SC right and left center wing consoles;

- SC on the right and left side wing consoles;

- SC on the horizontal tail.

Supply voltage on board - not less than 24 volts.

Additionally, a $24 \mathrm{~V}$ Li-Po battery must be installed on board the aircraft to provide power to the onboard consumers at night (during the descent of the pseudo-satellite) and at critical times when the sun is covered by clouds at altitudes of 0-6000 m. The power flows (and their distribution) of the SC and Li-Po batteries are controlled automatically by the respective controller and additional power supplies. The Li-Po battery should be housed in a special thermal box to maintain its performance at low temperatures. Solar cells on airplane surfaces must be covered with a transparent transparent film to protect against moisture and external damage.

\section{Estimated functional composition of the unmanned aerial vehicle demonstrator on SC}

The unmanned aerial vehicle demonstrator on the SC shall consist of the following units and systems [24]:

1. Glider including the chassis.

2. Power plant:

- engines;

- engine regulators;

- air screws.

3. Aviation equipment

3.1. Pilotage and navigation equipment:

-navigation equipment system;

-system of air signal sensors;

-onboard telemetry system.

3.2. Control system:

-servos of the control system;

-mechanical wiring of the control system;

-flight controller.

3.3. Automatic landing system.

4. System of power supply:

-onboard SC;

-onboard Li-Po batteries;

-power units;

-electrical wiring.

5. Lighting equipment (on-board air navigation lights).

6. Onboard objective control system:

- onboard data recorder.

7. On-board radio electronic equipment.

8. Radio equipment:

- satellite communications and navigation aids.

9. Equipment of radio lines:

- radio control facilities (board plane/ground - radio control; ground station/board plane telemetry); 
- video communication radio facilities (board plane /ground - target video).

Predictable design parameters of the aircraft for demonstrating flight at altitudes of up to 20 ths.m using onboard solar cells are shown in table 7 .

Table 7. Predictable design parameters of the aircraft using onboard solar cells.

\begin{tabular}{|c|c|c|}
\hline № & Parameter & The value \\
\hline 1 & Wingspan, $m$ & 11 \\
\hline 2 & Length, $\mathrm{m}$ & 4.8 \\
\hline 3 & Height, $\mathrm{m}$ & 1.1 \\
\hline 4 & Wingarea, $\mathrm{m}^{2}$ & $5.4-6.0$ \\
\hline 5 & MTOW, kg & $15-16$ \\
\hline 6 & Mass payload, kg & $\leq 1$ \\
\hline 7 & Empty aircraft mass in $\mathrm{SC}, \mathrm{kg}$ & 15 \\
\hline 8 & $\bar{N}, \mathrm{~W} / \mathrm{kg}$ & $28.5-30.0$ \\
\hline 9 & $\bar{m}_{\text {spec.load }}, \mathrm{kg} / \mathrm{W}$ & $\approx 0.033-0.035$ \\
\hline 10 & $\mathrm{p}_{0}, \mathrm{~kg} / \mathrm{m}^{2}$ & $\approx 2.5-3.5$ \\
\hline 11 & $\mathrm{~V}_{\max }, \mathrm{m} / \mathrm{s}(\mathrm{H}=0 \mathrm{~m})$ & 15 \\
\hline 12 & $\mathrm{~V}_{\text {max. }}, \mathrm{m} / \mathrm{s}(\mathrm{H}=20 \mathrm{~km})$ & 35 \\
\hline 13 & $\mathrm{~V}_{\mathrm{C}}, \mathrm{m} / \mathrm{s}(\mathrm{H}=0 \mathrm{~m})$ & 11 \\
\hline 14 & $\mathrm{~V}_{\mathrm{C}}, \mathrm{m} / \mathrm{s}(\mathrm{H}=20 \mathrm{~km})$ & 27 \\
\hline 15 & $\mathrm{~V}_{\mathrm{s}}, \mathrm{m} / \mathrm{s}(\mathrm{H}=0 \mathrm{~m})$ & 6 \\
\hline 16 & $\mathrm{~V}_{\mathrm{s}}, \mathrm{m} / \mathrm{s}(\mathrm{H}=20 \mathrm{~km})$ & 23 \\
\hline 17 & $\mathrm{~N}_{\text {eng. max., }} \mathrm{kW}$ & $2 \times 1.5=3$ \\
\hline 18 & Battery type & Li-Ion \\
\hline 19 & Working heights, ths. $\mathrm{m}$ & $18-20$ \\
\hline 20 & Practical ceiling, ths. $\mathrm{m}$ & 20 \\
\hline 21 & Flight time, $\mathrm{h}$ & $16-18$ \\
\hline 22 & Maximum range, $\mathrm{km}$ & 50 \\
\hline
\end{tabular}

\section{Conclusions}

In the first period of the development of the SC aircraft (1974-1990), the initial values of the specific load per unit area $\left(\mathrm{p}_{0}\right)$ and specific power $(\bar{N})$, were obtained, which had a wide range and were due to the low coefficient of utilization of solar energy (within 10\%), inefficient aerodynamic design and the use of traditional building materials; at the same time, significant results were achieved by R. Bousher (1974), whose drone had a very low specific load $-\mathrm{p}_{0}=1.4 \mathrm{~kg} / \mathrm{m}^{2}$ and specific power at $\bar{N}=28 \mathrm{~W} / \mathrm{kg}$, which was the beginning of the development of SC aircraft.

Further development of the aircraft at SC is characterized by a narrowing of the ranges of parameters $\mathrm{p}_{0}$ and $\bar{N}$; at the same time, airplanes are divided into groups; one group includes low-altitude (manned or unmanned) aircraft, including Solar Impulse and Atlantic Solar, which cannot be used for flights at altitude in the stratosphere; for example, the Solar Impulse is characterized by a significant value $\mathrm{p}_{0}=8,3 \mathrm{~kg} / \mathrm{m}^{2}$, which, together with the existing value $\bar{N}=21 \mathrm{~W} / \mathrm{kg}$, is not enough for flights at high altitudes.

Another group of exceptionally unmanned aircraft, including Pathfinder, PathfinderPlus and Zephyr, show a significant decrease in $\mathrm{p}_{0}$ to $\mathrm{p}_{0}=2.6 \ldots 3.6 \mathrm{~kg} / \mathrm{m}^{2}$, which in combination with a high $\bar{N}$ at $\bar{N}=23 \ldots 38 \mathrm{~W} / \mathrm{kg}$ allows to obtain adequate excess power for lifting the aircraft into the stratosphere and its long retention there in the light part of the day only with the help of SC.

Adopted design parameters of a stratospheric unmanned aerial vehicle - demonstrator of technologies with electric drive from SC are within the following limits: wingspan, m-11; 
wing area, $\mathrm{m}^{2}-5.5$; unit load per unit area, $\mathrm{p}_{0}=3 \mathrm{~kg} / \mathrm{m}^{2}$; specific power, maximum, $\bar{N}=$ $45 \mathrm{~W} / \mathrm{kg}$; the design MTOW of the aircraft is about $16 \mathrm{~kg}$.

The demonstrator aircraft must include the following major components and systems: glider including landing gear, power plant, airborne aviation equipment including flight and navigation equipment, power system including SC, control system including flight controller, automatic landing system, lighting equipment, on-board objective control system, on-board radio and electronic equipment and radio equipment.

\section{Author's contribution}

Volodymyr Isaienko provided preliminary project data with verification and supervised all work. Volodymyr Kharchenko organized the link between other authors and revised the manuscript. Mykhailo Matiychyk developed the concept based on the analysis and drafted the manuscript. All authors have read and approved the final version of the manuscript.

\section{Disclosure of the statement}

The authors reported that there were no conflicts of interest.

\section{References}

1. G. Tissandier, La Navigation aérienne, L'aviation et la direction des aerostats (Librairie Hachette, Paris, 1886)

2. Petróczy-Kármán-Žurovec.FromWikipedia, the free encyclopedia. https://en.wikipedia.org/wiki/Petr\%C3\%B3czy-K\%C3\%A1rm\%C3\%A1n-\%C5\%B Durovec

3. G. Mil, Electric drives for models (DOSAAF, Moscow, 1986)

4. Mauro Solar Riser. https://en.wikipedia.org/wiki/Mauro_Solar_Riser

5. Flight of the Worlds First Solar Powered Aircraft by Roland Boucher. http://www.projectsunrise. info/First_Solar_Powered_Aircraft

6. R.J. Boucher, AIAA/SAE/ASME 20th Joint Propulsion Conference, 1984. http://astrobobb.com/solarhistory.pdf

7. MacCready Solar Challenger. https://en.wikipedia.org/wiki/maccready_solar_challenger

8. NASA Armstrong Fact Sheet: Pathfinder Solar-Powered Aircraft. https://www.NASA.gov/centers/armstrong/news/FactSheets/FS-034-DFRC.html

9. Helios Prototype. https://en.wikipedia.org/wiki/Helios_Prototype

10. AeroVironment. https://en.wikipedia.org/wiki/AeroVironment

11. T.E. Noll, J.M. Brown, M.E. Perez-Davis, S.D. Ishmael, G.C. Tiffany, Investigation of the Helios Prototype Aircraft Mishap (Create Space Independent Publishing Platform, 2012). ISBN-10: 1480279854.

12. N.J. Colella, G.S. Wenneker, Lawrence Livermore National Laboratory, 1-9 (1994). https://str.1lnl.gov/content/pages/past-issues-pdfs/1994.07.pdf

13. Solar Impulse. https://ru.wikipedia.org/wiki/Solar_Impulse

14. D. Mamontov, Journal Popular Mechanics 3(149) (2015)

15. Solar Impulse. https://en.wikipedia.org/wiki/Solar_Impulse 
16. Solar Impulse Sets World Record: 117 Hours \& 52 Minutes — Longest Solo Flight Ever. https://cleantechnica.com/2015/07/06/solar-impulse-sets-world-record-117hours-52-minutes-longest-solo-flight

17. Zephyr Solar-Powered HALE UAV. https://www.airforcetechnology.com/projects/zephyr/

18. J. Amos. BBC Science, (2016). https://www.bbc.com/news/science-environment35478489

19. Facebook stops developing a drone to spread the Internet. https://bykvu.com/ru/bukvy/94258-v-facebook-prekrashchayut-razrabotkubespilotnika-dlya-razdachi-interneta/

20. The United States tested an unmanned biplane with solar panels. https://ukrmach.dp.ua/2018/10/24/ssha-ispytali-bespilotnyj-biplan-s-solnechnymipanelyami.html/amp.

21. PHASA-35. Access: http://prismaticltd.co.uk/products/phasa-35/

22. S.M. Eger, V.F. Mishin, Aircraft design (Mechanical Engineering, Moscow, 1983)

23. S. Gudmundsson, General aviation aircraft design: applied methods and procedures (Butterworth-Heinemann, USA)

24. M.P. Matiychyk, V.P. Kharchenko, Unmanned aerial vehicle for flights in the stratosphere. Pat. Ukraine for utility model №135771 (2019) 